\title{
A Rare Red Morph of a Buff-striped Keelback, Amphiesma stolatum (Linnaeus 1758), in Sawantwadi City, Maharashtra, India
}

\author{
Lalit Ghadi ${ }^{1}$ and Kishor Shirkande ${ }^{2}$ \\ 'Military Boys' Hostel, Sawantwadi City, Sindhudurg District, Maharashtra 416510, India (lalitghadi55@gmail.com) \\ ${ }^{2}$ Department of Zoology, Prof. Ramkrishna More College of Science, Akurdi, Pune 411044, India (wildlife.kishor@gmail.com)
}

Photographs by the senior author.

$\mathrm{B}$ uff-striped Keelbacks (Amphiesma stolatum) are nonvenomous natricid snakes that range throughout the Indian Subcontinent. These predominantly diurnal snakes are most frequently encountered during the rainy season (June-September) when males are searching for mates and females are laying eggs (Whitaker and Captain 2004; Pryce et al. 2016). Typical dorsal ground color of the head and body is olive-brown to gray with two chrome-yellow dorsolateral lines and a series of black crossbands; sides of the head are either yellow or white; the venter is pale yellowish or cream. During the mating season, females temporarily acquire some reddish

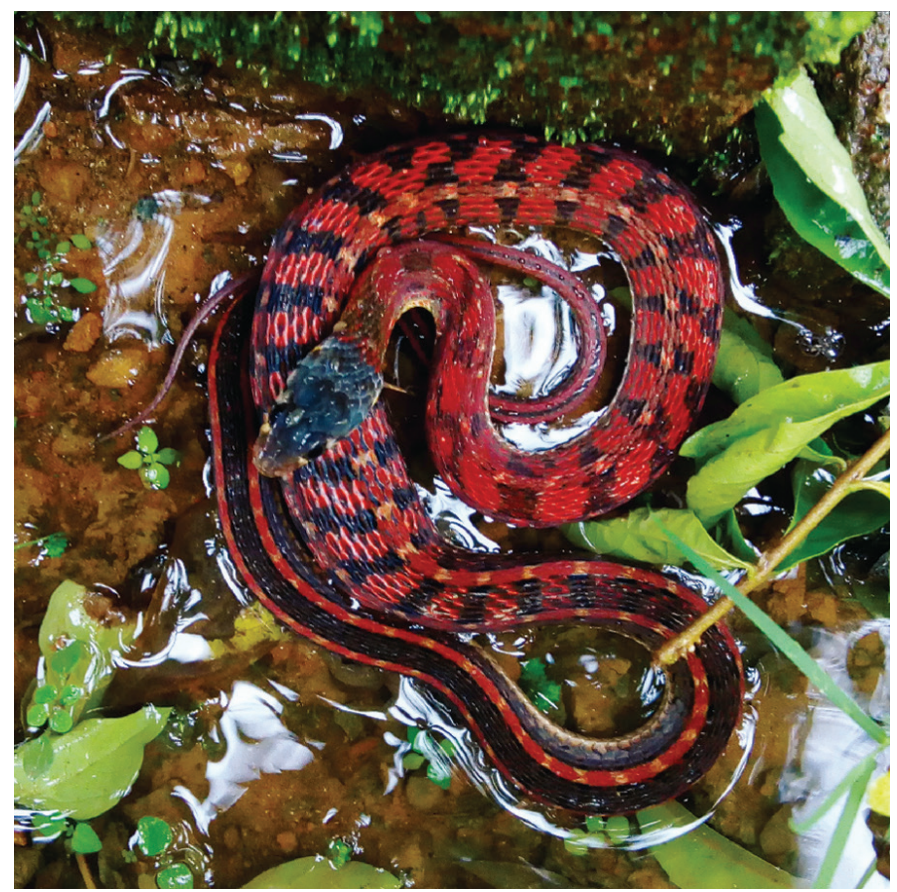

Fig. 1. Red color morph of a Buff-striped Keelback (Amphiesma stolatum) found in a small puddle in Sawantwadi City, Sindhudurg District, Maharashtra, India.

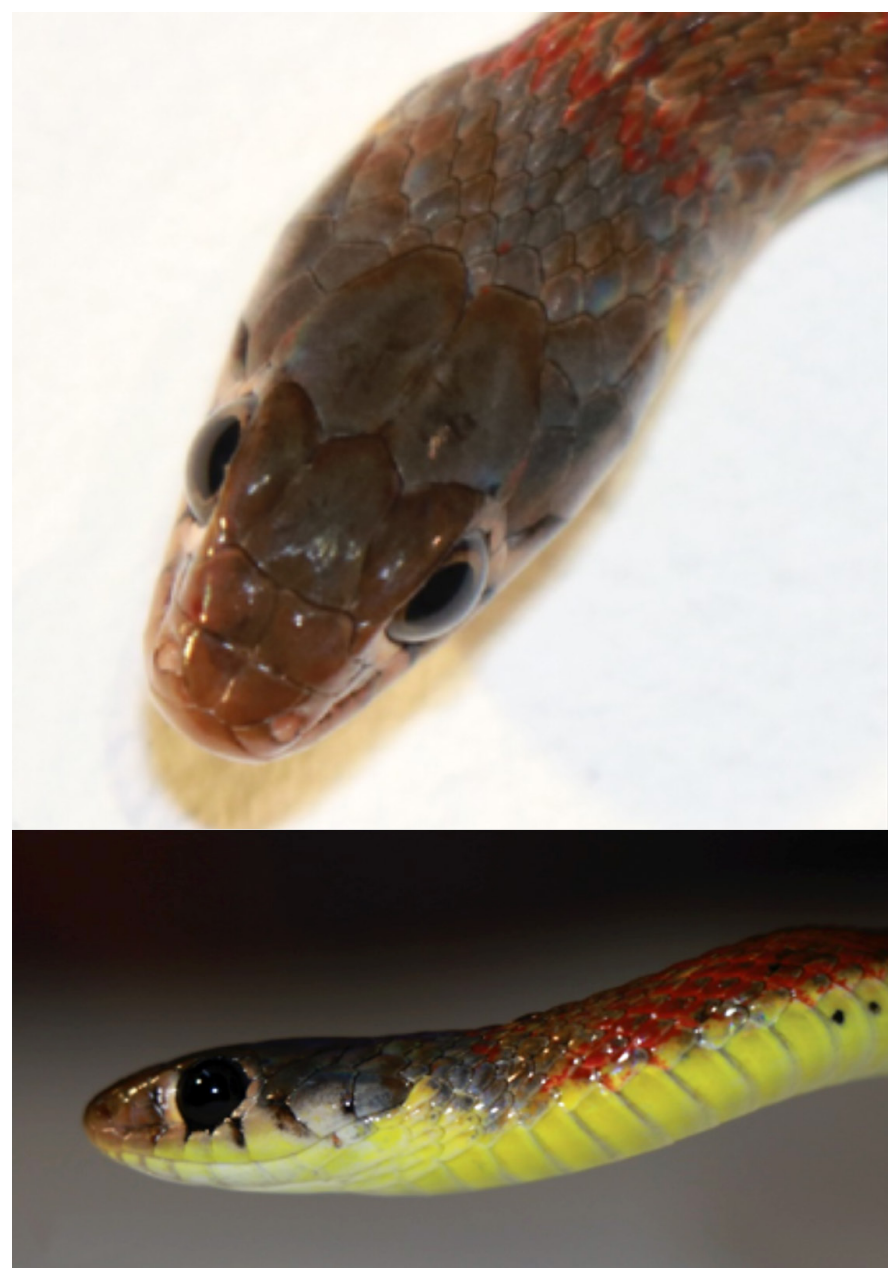

Fig. 2. The head of a red Buff-striped Keelback (Amphiesma stolatum) from Sawantwadi City showing characteristic scalation.

coloration around the neck. Red morphs have been encountered some $600 \mathrm{~km}$ to the south in Manipal (http://manipalblog.com/2011/09/12/manipal-snake-watch/) and Bangalore 


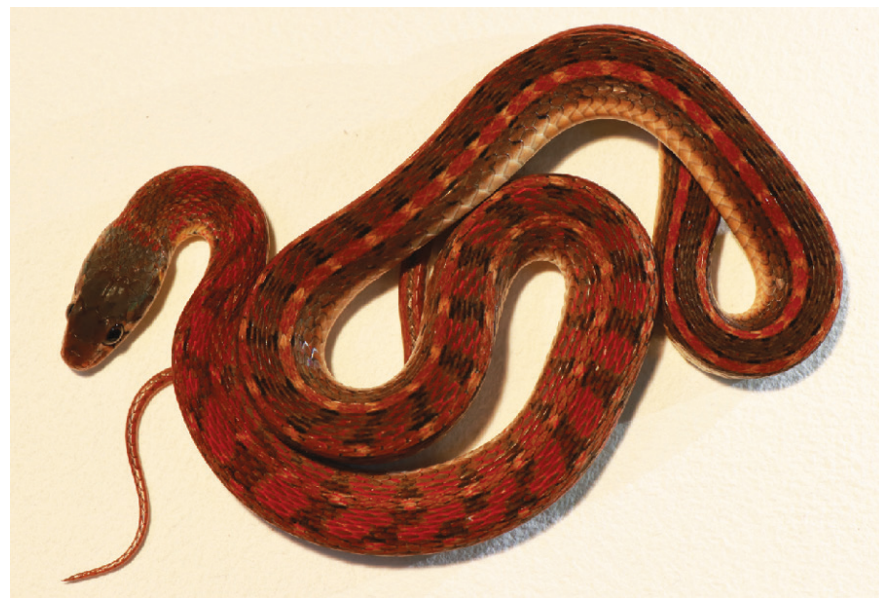

Fig. 3. A red Buff-striped Keelback (Amphiesma stolatum) from Sawantwadi City showing characteristic pattern elements.

(http://www.alamy.com/stock-photo-buff-striped-keelbackamphiesma-sp-bangalore-india-thebuff-striped-138945068. html?pv=1\&stamp=2\&imageid=0CA2AF1F-BC6F-40098AD2-03FA2F585), Karnataka, but we are unaware of reports of this color variant from elsewhere in India.

At about 1400 h on 4 July 2017, the senior author responded to a rescue call at the Military Boys' Hostel in Sawantwadi $\left(15.90^{\circ} \mathrm{N}, 73.81^{\circ} \mathrm{E}\right.$, elevation $\left.112 \mathrm{~m}\right)$, where he found a red female Buff-striped Keelback with an olivebrown head laying in a puddle (Fig. 1). Total length was 533 $\mathrm{mm}$ and the snake appeared to have just eaten. Despite the unusual coloration, meristics and pattern elements (Figs. $2 \&$ 3) were well within ranges listed by Whitaker and Captain (2004): 8 supralabials, the 3 rd to 5 th touching the eye, 148 (118-161) ventrals, and 77 (46-89) paired subcaudals; dorsolateral lines (albeit red rather than yellow) and black crossbands were present.

\section{Acknowledgements}

We are grateful for support provided by Dr. Ganesh Margaj Sir, Assistant Professor of Zoology, SPK College of Sawantwadi. We also thank Prof. Siddhesh Nerurkar and the final-year students of B.S. Bandekar College of Fine Arts, Sawantwadi, Batch 2017-18 for assistance in documenting the specimen, the Sawantwadi Forest Department, and Mr. Aniket R. Kadam, founder of the Wildlife Welfare Association (WWA) Thane, for ongoing support.

\section{Literature Cited}

Pryce, D., J. Thorpe, S. Kulkarni, and T.R. Lewis. 2016. Amphiesma stolatum (Striped Keelback): Habitat and reproduction. Herpetological Bulletin 136: 37-38

Whitaker, R. and A. Captain. 2004. Snakes of India, The Field Guide. Draco Books, Chennai, India. 